\title{
Meliponini biodiversity and medicinal uses of pot-honey from El Oro province in Ecuador
}

\author{
Vit Patricia ${ }^{1,2,3^{*}}$, Vargas Oliverio4, López Triny4, Maza Favián ${ }^{5}$ \\ ${ }^{1}$ Currently: Prometeo Researcher, Faculty of Agricultural and Livestock Sciences, Universidad Técnica de Machala, Machala, El Oro, Ecuador, \\ ${ }^{2}$ Food Science Department, Faculty of Pharmacy and Bioanalysis, Universidad de Los Andes, Mérida 5101 , Venezuela; ${ }^{3}$ Honorary Associate \\ Biomedical Sciences, School of Medical Sciences, The University of Sydney, 75 East Street, Lidcombe, NSW 1825, Australia; ${ }^{4}$ Faculty of \\ Agricultural and Livestock Sciences; Universidad Técnica de Machala, Machala, El Oro, Ecuador; ${ }^{5}$ Planning Department, Universidad Técnica \\ de Machala/Av. Panamericana Km 51/2 Via Pasaje, Machala, El Oro, Ecuador
}

\section{A B S TR A C T}

Ecuadorian stingless bees (Apidae, Meliponini) have ethnomedicinal interest because their products are used in healing. Diverse remedies consist on pot-honey alone or mixed with infusions. This set of medicinal uses were informed in El Oro province by Ecuadorian stingless bee keepers -known as meliponicultors - in Latin America: Bruises, tumors, ocular cataracts, pterygium, inflammation, infections, varicose veins, cleaning blood after childbirth, kidney diseases, tumor, wound healing, and soothing balm before sleeping. Scaptotrigona ederi named "catiana" or "catana" is the most frequent bee in the visited cantons Las Lajas, Balsas, Piñas, and Zaruma. Other important stingless bees are Melipona indecisa "cananambo", Melipona mimetica "bermejo", Nannotrigona cf. perilampoides "pitón", and Paratrigona aff. eutaeniata "pirunga". A bioprospective research will follow to value this ancient tradition and the honey processed in cerumen pots, with sound inclusion in the Ecuadorian honey regulation NTE INEN 1572, currently under revision.

Keywords: Ecuador; Geotrigona; Medicinal uses; Melipona; Meliponini; Pot-honey; Scaptotrigona

\section{INTRODUCTION}

Ecuador has a surface of almost $300,000 \mathrm{~km}^{2}$ divided into 24 provinces with the highest biodiversity in the planet. El Oro province is divided into 14 cantones, and belongs to the region 7 of Ecuador, located in the South West of the country, besides Loja and Zamora Chinchipe provinces (Fig. 1). El Oro's population is 559,846 inhabitants living in $5,850 \mathrm{~km}^{2}$-roughly $1 / 50$ the country surface; the capital city Machala is internationally known as the banana capital of the world. Besides the ecologically controversial exploitation of shrimp farming and intensive banana plantations, El Oro province has protected areas: Arenillas Ecological Reserve, Buenaventura National Park and Isla Santa Clara Wildlife Sanctuary. This coastal province is home to the Mullopungo, Chilla and Tioloma foothills, Hummingbird Sanctuary, and stingless bees.

Las Lajas is a $300 \mathrm{Km}^{2}$ Southern West canton of El Oro province, capital La Victoria, known for the production of cocoa, corn, and livestock. The temperature of 19 to $30^{\circ} \mathrm{C}$, and altitudes between 80 and 900 m.a.s.l. are good for stingless bee life, indeed few species are currently kept.

Stingless bees (Hymenoptera; Apidae; Meliponini) are a tropical group with more than 500 known species, and perhaps 100 more to be named (Michener, 2013). This great biodiversity is mostly represented by Neotropical Meliponini with almost 400 species group (Camargo and Pedro, 2007; Camargo, 2013). Different species of stingless bees thrive in El Oro province, and some of them are used in traditional meliponiculture. The following species of stingless bees were previously reported in this province (Ramírez et al., 2012): Cephalotrigina capitata Smith,1854; Geotrigona fumipennis, Camargo \& Moure, 2066; Oxytrigona mellicolor, Packard, 1869; Scaptotrigona sp. cf. postica, Scaptotrigona sp., Trigona fulviventris, Trigona matera, Trigonisca sp. 1 and sp. 2.

"Stingless bees process honey and pollen in cerumen pots" is the title of an e-book, to reflect on differences from and similarities to honey and pollen processed in beeswax

\footnotetext{
${ }^{*}$ Corresponding author:

Vit Patricia, Prometeo Researcher, Faculty of Agricultural and Livestock Sciences, Universidad Técnica de Machala, Machala, El Oro, Ecuador. E-mail: vitolivier@gmail.com
} 
combs (Vit and Roubik, 2013). See honey and pollen pots from a nest of "catana" Scaptotrigona ederi in Chiriboga, Libertad parrish, Las Lajas canton, El Oro province, Ecuador (Fig. 2).

Knowledgeable medicinal properties of honey produced by stingless bees from Guatemala, Mexico and Venezuela were informed (Vit et al., 2004). Achuars from the Amazonian forest of Ecuador treat throat inflammation with pot-honey (Guerrini et al., 2009). Honey -as an effective curative product with religious and mythical powers- was pinpointed in a retrospective review on the medicinal uses of Melipona beecheii pot-honey by the ancient Maya to restore balance of ill patients (Ocampo Rosales, 2013). Pot-honey was a name suggested to group honey produced by Meliponini because stinglessness intellectual term used by Michener (2013) - possibly gives no input to think on the process by which honey is made inside cerumen containers, a component that may explain bioactive properties (Vit et al., 2013).

Natives from South America, such as the Kayapós, from southern Pará, Brazil, use the products of stingless bees in food and medicine, and also as a model for social organization for their own communities (Posey and Camargo, 1985; Camargo and Posey, 1990). Local knowledge on medicinal use, management and ecological aspects were studied in a contribution of ethnoentomology for eight stingless bee species from Michoacan, Mexico (Reyes-González et al., 2014).

In this work we studied Ecuadorian meliponines from Las Lajas, Balsas, Piñas, and Zaruma cantons from El Oro province and the different medicinal uses of their honey produced in cerumen pots, to retrieve the relation manbee-environment-health.

\section{MATERIALS AND METHODS}

Stingless bee keepers -named meliponicultors in Latin America- were visited in four cantons (Las Lajas, Balsas, Piñas, and Zaruma) from Provincia El Oro in Ecuador. Questionnaires were used with seventeen meliponicultors, six female and eleven male, to inform medicinal uses of pot-honey by themselves and pot-honey consumers. The questionnaire consisted in 15 structured questions on Personal Identification (1. Name, 2. Surname, 3. Age, 4. Location, 5. Phone, 6. Email); Meliponiculture (7. Years of experience, 8. Ethnic names of species kept, 9. Origin of the Nests, 10. Rational or traditional meliponary, 11. Number of hives, 12. Products extracted, 13. Method of honey extraction, 14. Conservation of the honey); 15. Medicinal uses of pot-honey were elicited by

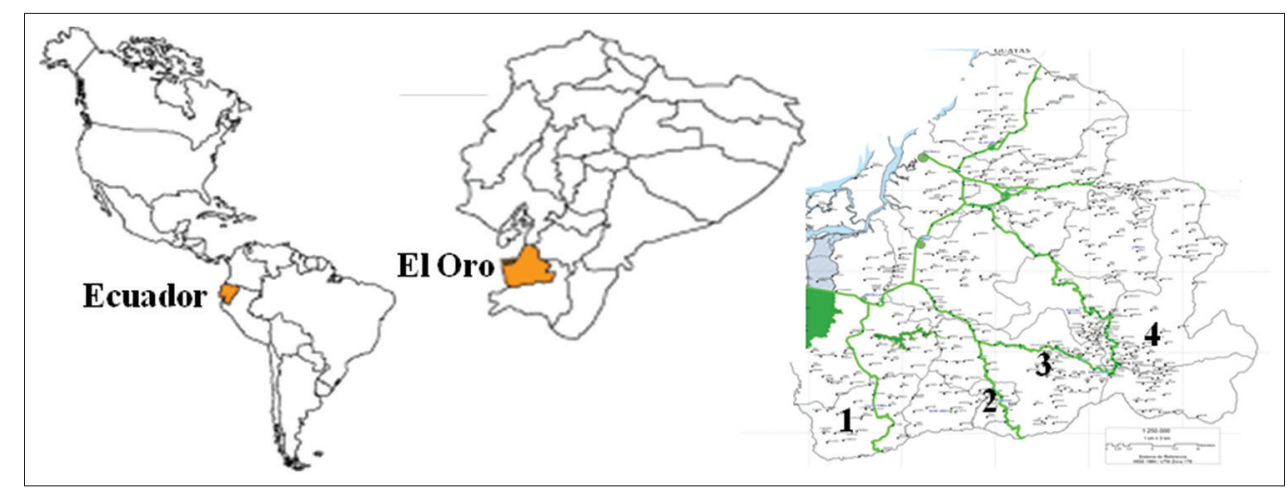

Fig 1. Location of El Oro province in the Southwest of Ecuador, 1. Las Lajas, 2. Balsas, 3. Piñas, and 4. Zaruma cantons. (From: http://www.parks.it/world/EC/Eindex.html)

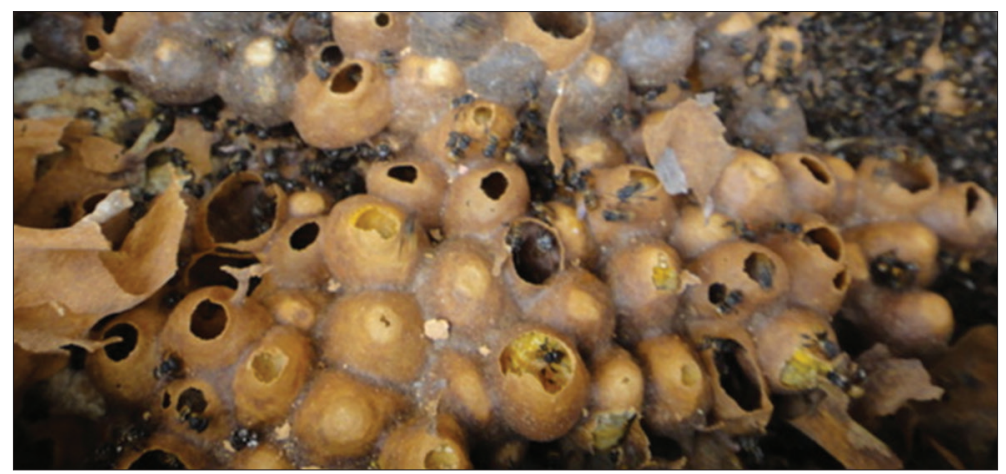

Fig 2. Honey and pollen pots from "catana" Scaptotrigona ederi. 
enumeration and listening cases. Data on medicinal uses of pot-honey were analyzed and summarized by using Microsoft Excel to determine relative frequencies (\%) of citations so as to identify the most common and popularly uses in the studied area.

The behavior of the bees was observed, and information on type of meliponary, and shape of the nest entrance was recorded. Ethnic names of the stingless bees were taken in each sampling, and used for preliminary identification (Ramírez et al., 2013). Stingless bees were collected in isopropyl alcohol, kept in boxes, and sent to Dr. S.R.M. Pedro, Camargo's Collection, Biology Department, Universidade de São Paulo, Ribeirão Preto, Brazil, for entomological identification. Another set was sent to Prof. J. Ramírez for subsequent mounting to be deposited in entomological boxes at Universidad Nacional de Loja, Loja, Ecuador. Further duplicates were sent to Professor Charles D. Michener at the University of Kansas, Lawrence, USA; to Dr. Clifford Keil, Director of the Invertebrates Museum, Pontificia Universidad Católica de Ecuador, Quito, Ecuador; and Dr. David W. Roubik, Smithsonian Tropical Research Institute; Panama.

\section{RESULTS AND DISCUSSION}

Stingless bees kept by seventeen visited Ecuadorian meliponicultors, aged 12 to 76-y-o in El Oro province are "bermeja" Melipona mimetica Cockerell, 1914; "cananambo" Melipona indecisa, Cockerel, 1919; "catiana" or "catana" Scaptotrigona ederi Schwarz, unpublished; "pirunga" Paratrigona aff. eutaeniata Camargo \& Moure, 1994, "piton" Nannotrigona cf. perilampoides (Cresson, 1878). All of them commented on decrease of "bermejo" and "cananambo" nests as a more sensitive bee in frank decrease.

The dark Scaptotrigona ederi has variable defensive behavior, generally entangles in the hair and bites, therefore the use of the veil is advised for harvesting. The other species mentioned here are gentle bees, Nannotrigona sp. hides easily inside the nest. Two of the interviewed meliponicultors kept more than one type of stingless bee species, namely Melipona indecisa and Scaptotrigna ederi, Melipona mimetica and
Scaptotrigna ederi; whereas a female meliponicultor kept Nannotrigona cf. perilampoides, Paratrigona aff. eutaeniata. and Scaptotrigna ederi. In Table 1 we show the ethnomedicinal uses of pot-honey produced by these five species of stingless bees, with healing properties known by producers and consumers in the locality. In this work the simple expressions were chosen to group the way honey is used, instead of systemic categorizations of medicinal interventions. The use of mixtures with plants would deserve another work by its own, therefore only the pothoney is considered here.

Pot-honey is widely used alone or mixed with medicinal plants to treat tumors, eyes (ocular cataracts, pterygium), inflammation, sour throat infections, blood (bruises, varicose veins, purifying blood, cleaning blood after childbirth), kidney diseases, wound healing, and soothing balm before sleeping. The most frequent medicinal use was related to blood in $27 \%$ of the reported uses.

Their sensory qualities are appreciated by meliponicultors, who perceive floral smell and enticing sour flavor. In Table 1, the ethnic and scientific names of five stingless bee species from El Oro province are given with the medicinal uses of the pot-honey attributed by meliponicultors investigated here. Eight healing effects were registered, and besides being the most frequent, "catiana" or "catana" pot-honey has all these putative medicinal properties. Generally meliponicultors do not keep Apis mellifera, but the uses of honey are similar as a sweetener in plant infusions with antiinflammatory, emollient, against colds, and invigorative properties, as reported in the Granada study (Benítez, 2011). In the review on edible insects of Ecuador (Onore, 2005) and in our study, medicinal uses of stingless bee bodies were not informed by stingless bee keepers. However, whole body extracts of bees are used as anticancer and antibacterial agents, namely for their antimicrobial peptides (AMPs) (Ratcliffe et al., 2011).

Insects represented the major animal group (23\%) of folk medicinal bio-resources in the study of Bahia, Brazil (Costa-Neto, 2004). Therefore entomotherapy has implications for public health and biological conservation

Table 1: Ethnomedicinal uses of pot-honey produced by five types of stingless bees in El Oro province

\begin{tabular}{|c|c|c|c|c|c|c|c|c|c|c|c|}
\hline \multicolumn{2}{|r|}{ Stingless bee names } & \multirow[t]{2}{*}{$\mathrm{n}$} & \multirow[t]{2}{*}{ Canton location } & \multicolumn{8}{|c|}{ Healing uses (\%) } \\
\hline Ethnic & Scientific & & & Balm & Blood & Kidney & Eyes & Inflammation & $\begin{array}{l}\text { Sour } \\
\text { throat }\end{array}$ & Tumor & $\begin{array}{l}\text { Wound } \\
\text { healing }\end{array}$ \\
\hline "bermeja" & Melipona mimetica & 1 & Las Lajas & - & 2.7 & 2.7 & 2.7 & 2.7 & 2.7 & - & - \\
\hline "cananambo" & Melipona indecisa & 1 & Piñas & - & - & - & - & - & 2.7 & - & - \\
\hline $\begin{array}{l}\text { "catiana" } \\
\text { "catana" }\end{array}$ & Scaptotrigona ederi & 13 & $\begin{array}{l}\text { Balsas, Las Lajas, } \\
\text { Piñas, Zaruma }\end{array}$ & 5.4 & 27.1 & 5.4 & 8.1 & 13.5 & 10.8 & 5.4 & 2.7 \\
\hline "pirunga" & Paratrigona aff. eutaeniata & 1 & Las Lajas & - & - & - & 2.7 & - & - & - & - \\
\hline "piton" & Nannotrigona cf. perilampoides & 1 & Las Lajas & - & - & - & 2.7 & - & - & - & - \\
\hline
\end{tabular}


(Alves and Alves, 2011); in their review 18 species of stingless bees were retrieved in studies on medicinal properties. However, compared to fitotherapy, the number of studies on zootherapy is very limited. Antibacterial and antioxidant activity of honey vary according to the botanical and entomological (Rodríguez-Malavaer et al., 2007) origin. The bioactive properties of honey are ascribed to specific factors such as the synergistic action of sugar and hydrogen peroxide for wound healing (Kwakman et al., 2010).

Further ongoing studies are of interest to identify the megabiodiversity of stingless bees in Ecuador, the traditional meliponiculture, and medicinal uses of pothoney as ancestral knowledge. Although these pot-honeys were produced and used before Columbus, they are not yet considered in the honey regulations (Vit, 2008). This joint effort besides the characterization of pot-honeys, and its inclusion in the honey standards of the INEN 1572 regulation (Vit et al., unpublished), using the Melipona favosa pot-honey model (Vit, 2013), would increase its current value in the market up to USD $27 / \mathrm{kg}$, promote the study of its medicinal properties and praise the activity of meliponicultors. The role of honey is perceived therapeutic in $90 \%$ of multispecies medicinal recipes.

Traditional medicine (TM) remains a simple therapy for health care in low income countries because it is the most available and affordable form of healing, as well as for the naturism philosophy, and combined with alopatic medicine as complementary alternative medicine (CAM) (WHO, 2000). It is readily available in ethnic groups such as Pankararé from Brazil who use Frieseomelitta sp., Cephalotrigona cf capitata, Melipona sp., Melipona scutellaris, Partamona cf. cupira, Tetragonisca sp., Trigona (Trigona) spinipes, Plebeia sp., pot-honey or pollen eaten or mixed with plants (Costa-Neto, 2002). The fact that pot-honey has cultural value connecting with ancient curative skills, does not exclude its use as raw material in the preparation of industrial drugs.

The ecological contribution of stingless bees as organisms is encapsulated in their pollinating service to about $50 \%$ of flowering plant species in the Neotropics (Biesmeijer, 1997) and Australia (Heard, 1999). The role of honey is perceived as therapeutic in $90 \%$ of multispecies medicinal recipes from Misiones, Argentina (Kujawsca, 2012).

Stingless bee keepers from Zona Maya in Mexico experienced colony losses of Melipona beecheii due to competition for food (Villanueva-Gutiérrez et al., 2013), especially in meliponaries with more than 100 nests. Besides the rescue of tradition, environmental protection is needed to achieve sustainable meliponiculture. To protect wild populations of stingless bees, the Ecuadorian Ministry of Environment started to fine extractions of nests from wild logs five years ago in Las Lajas canton from El Oro province, as informed by a meliponicultor from Amarillos, parrish La Libertad (M. Estrada, personal communication). Besides the nutritional, organoleptic and sanitary values of a medicinal food like honey, an enterprising concept on the quality of the agri-food systems -as reviewed by Monastra and Crisponi (2013), considers animal welfare and defence of the ecosystem, as practiced by stingless bee keepers in modern days.

\section{CONCLUSIONS}

Honey is a medicinal food product of plant-animalbased pharmacopeia used in entomotherapy. Seventeen meliponicultors provided information on the honey produced in cerumen pots by five types of stingless bees from el Oro province from Ecuador. Pot-honey is mostly harvested from "catana" or "catiana" because the other bees -"bermeja", "cananambo", "pirunga" anf "piton"- are less frequent. This described knowledge has ecological and sanitary implications, and deserves careful considerations.

\section{ACKNOWLEDGEMENTS}

To Prometeo, Senescyt, Ecuador for the grant to Patricia Vit at Universidad Técnica de Machala UTMACH, Provincia El Oro. To Dr. Silvia R.M. Pedro, Biology Department, Universidade de São Paulo, Ribeirão Preto, Brazil, for the entomological identifications. To Gobierno Autónomo Descentralizado Provincial El Oro GADPEO, for the map with the cantons studied here. To Mrs. Elizabeth Brito Administrative Assistant from the Planning Department, and Mrs. Esperanza Poma Bustos, Director of Public Relations, for the efficient logistics, the Principal of UTMACH Eng. César Quezada Abad for the facilities provided for field work, and the drivers Mr. Jairo Riofrio, Mr. Wilson Ríos, and Mr. Francisco Saavedra. To Prof. José Quevedo from UTMACH for the initial contact with pot-honey producers from Piñas. To El Oro province Ecuadorian meliponicultors Evita María Guairacocha Pereira, Ubertino Matamoro, María Torres, Andrés Torres, Graciela Pacheco, Segundo Feijó, Arturo Balareso, Oswaldo Ajila, Guillermo Feijoó, César and Nayeli Jaramillo, Segundo Lapo, Abelardo Román, Rosa and Marina Estrada, Daniel and José Zúñiga from Ecuador to keep the tradition beyond ancient times. Professor Genoveva Ocampo Rosales from the Faculty of Phylosophy and Letters, Universidad Nacional Autónoma de México, and Professor Maurizio Paoletti from the Department of Biology, Universitá di Padova, Italy, kindly 
revised our manuscript. To Productos Schullo for the support to present a poster of this research in the $23^{\text {rd. }}$ SILAE congress, Marsala, Sicily, Italy, 2014.

\section{Author contributions}

V. P. made a major contribution to design the research and collect the data. L.T. contributed with field work in Las Lajas. V. O. and M. V. F. were involved in overall supervision as Prometeo Counterparts. All authors read and approved the final manuscript.

\section{REFERENCES}

Alves, R. R. N. and H. N. Alves. 2011. The faunal drugstore: Animalbased remedies used in traditional medicines in Latin America J. Ethnobiol. Ethnomed. 7: 9-43.

Benítez, G. 2011. Animals used for medicinal and mágico-religiuos purposes in Western Granada Province, Andalusia (Spain). J. Ethnopharmacol. 137: 1113-1123.

Biesmeijer, J. C. 1997. Abejas sin aguijón: Su biología y la organización de la colmena. Elinkwijk BV, The Netherlands.

Camargo, J. M. F. 2013. Historical biogeography of the meliponini (Hymenoptera, Apidae, Apinae) of the Neotropical Region. In: P. Vit, S. R. M. Pedro and D. W. Roubik, editors. Pot-honey. A Legacy of Stingless Bees, Springer, N. Y. pp. 19-34.

Camargo, J. M. F. and S. R. M. Pedro. 2007. Meliponini Lepeletier, 1836. In: J. S. Moure, D. Urban and G. A. R. Melo, editors. Catalogue of Bees (Hymenoptera, Apoidea) in the Neotropical Region. Sociedade Brasileira de Entomologia, Curitiba, Brasil. pp. 272-578.

Camargo J. M. F and D. A. Posey. 1990. O conhecimento dos Kayapó sobre as abelhas sociais sem ferrão (Meliponidae, Apidae, Hymenoptera): Notas adicionais. Bol. Mus. Paraense Emílio Goeldi, Série Zoologia. 6: 17-42.

Costa-Neto, E. M. 2002. The use od insects in folk medicine in tha State of Bahia, Northeastern Brazil, with notes on insects Reported elsewhere in Brazilian folk medicine. Hum. Ecol. 30: 245-263.

Costa-Neto, E. M. 2004. Implications and applications of folk zootherapy in the state of Bahia, northeastern Brazil. Sust. Dev. 12: 161-174.

Guerrini, A., R. Bruni, S. Maietti, F. Poli, D. Rossi, G. Paganetto, M. Muzzoli, L. Scalvenzi and G. Sacchetti. 2009. Ecuadorian stingless bee (Meliponinae) honey: A chemical and functional profile of an ancient health product. Food Chem. 114: 1413-1420.

Heard, T. 1999. The role of stingless bees in crop pollination. Ann. Rev. Entomol. 44: 183-206.

INEN, 1988. Norma Técnica Ecuatoriana Obligatoria. Miel de Abejas, Requisitos. NTE INEN 1572, Quito, Ecuador. p. 1-4.

Kuwaska, M., F. Zamudio and N. I. Hilgert. 2012. Honey-based mixtures used in home medicine by nonindigenous population of Misiones, Argentina. Evid Based Complement. Alternat. Med. Article ID 579350. doi 10.1155/2012/579350.

Kwakman, P. H. S., A. J. Te Velde, L. De Boer and D. Speijer, C. M. J. Vandenbroucke-Grauls and S. A. J. Zaat. 2010. How honey kills bacteria. FASEB J. 24: 2576-2582.

Michener, C. D. 2013. The Meliponini. In: P. Vit, S. R. M. Pedro and D. W. Roubik editors. Pot-Honey: A Legacy of Stingless Bees. Springer, N. Y. pp. 3-17.
Monastra, G. and G. Crisponi. 2013. The concept of Agri-Food quality in its different meanings. J. Nutr. Ecol. Food Res. 1: 167-184.

Ocampo Rosales, G. R. 2013. Medicinal Uses of Melipona beecheii Honey, by the ancient Maya. In: P. Vit, S. R. M. Pedro and D. W. Roubik, editors. Pot-Honey: A Legacy of Stingless Bees. Springer, N. Y.

Onore, G. 2005. Edible insects in Ecuador. In: M. G. Paoletti, editor. Ecological Implications of Minilivestock. Potential of Insects, Rodents, Frogs and Snails. Science Publishers, Inc., New Hampshire. pp. 343-352.

Posey, D. A. and J. M. F Camargo. 1985. Additional notes on the classification and knowledge of stingless bees (Meliponinae, Apidae, Hymenoptera) by the Kayapó Indians of Gorotire, Pará, Brazil. Ann. Carnegie Mus 54: 247-274.

Ramírez, J. A., J. Ureña and A. Camacho. 2012. Las abejas sin aguijón (Apidae: Meliponini) de la Región Sur del Ecuador. Estudios Universitarios (s/v): 104-111.

Ramírez, J. A., J. Ureña and A. Camacho. 2013. Las abejas sin aguijón de la Región Sur del Ecuador. Consejo Nacional de Educación Superior, Loja, Ecuador. p. 119.

Ratcliffe, N. A., C. B. Mello, E. S. García, T. M. Butt and P. Azambuja. 2011. Insect natura products and processes: New treatments for human disease. Insect. Biochem. Mol. Biol. 4: 747-769.

Reyes-González, A., A. Camou-Guerrero, O. Reyes-Salas, A. Argueta and A. Casas. 2014. Diversity, local knowledge and use of stingless bees (Apidae: Meliponini) in the municipality of Nocupétaro, Michoacan, Mexico. J. Ethnobiol. Ethnomed. 10: 1-12.

Rodríguez-Malaver, A. J., E. M. Pérez-Pérez and P. Vit. 2007. Capacidad antioxidante de mieles venezolanas de los géneros Apis, Melipona y Tetragonisca, evaluada por tres métodos. Rev. Inst. Nac. Hig. Rafael Rangel. 38: 13-18.

Villanueva-Gutiérrez, R., D. W. Roubik, W. Colli-Ucán, F. J. GüemezRicalde and S. L. Buchmann. 2013. A critical view of colony losses in managed Mayan honey-making bees (Apidae: Meliponini) in the heart of Zona Maya. J. Kansas Entomol. Soc. 86: 352-362.

Vit, P. 2008. La miel precolombina de abejas sin aguijón (Meliponini) aún no tiene normas de calidad. Rev. Bol. Centro Investigaciones Biológicas 42: 415-423.

Vit, P. 2013. Modificaciones comentadas de la norma Miel de Abejas, hacia la norma Miel de Venezuela: Inclusión de miel de pote y exclusión de mieles falsas. In: P. Vit and D. W. Roubik, editors. Stingless bees process honey and pollen in cerumen pots. Facultad de Farmacia y Bioanálisis, Universidad de Los Andes, Mérida, Venezuela. pp. 1-8. Available from: http://www.saber. ula.ve/handle/123456789/35292.

Vit, P., M. Medina and M. E. Enríquez. 2004. Quality standards for medicinal uses of Meliponinae honey in Guatemala, Mexico and Venezuela. Bee World. 85: 2-5.

Vit, P., S. R. M. Pedro and D. W. Roubik, editors. Pot-Honey: A Legacy of Stingless Bees. Springer, N. Y.

Vit, P. and D. W. Roubik, editors. Stingless bees process honey and pollen in cerumen pots. Facultad de Farmacia y Bioanálisis, Universidad de Los Andes, Mérida, Venezuela. Available from: http://www.saber.ula.ve/handle/123456789/35292.

WHO - World Health Organization. 2002. Traditional Medicine. Strategy 2002-2005. WHO/EDM/TRM, Genevea, Switzerland. Available from: http://www.wpro.who.int/health_technology/ book_who_traditional_medicine_strategy_2002_2005.pdf. 